\title{
PENGARUH PENGENDALIAN INTERNAL, GOOD GOVERNANCE DAN PEMANFAATAN \\ TEKNOLOGI INFORMASI TERHADAP KINERJA PEGAWAI BAGIAN KEUANGAN PADA SKPD DI KABUPATEN INDRAGIRI HILIR
}

\author{
HERDA NENGSY ${ }^{1}$ \\ Universitas Islam Indragiri Tembilahan \\ Email : herdanengsy@gmail.com \\ R. DESI KARLINA ${ }^{2}$ \\ Universitas Islam Indragiri Tembilahan \\ Email : rajadesikarlina15@yahoo.com
}

\begin{abstract}
This study aims to test and obtain empirical evidence of the influence of internal control, good governance and the use of information technology on employee performance in the financial section of the $S K P D$ in Indragiri Hilir Regency. The population in this study were employees of the finance department at the SKPD in Indragiri Hilir Regency. The sample selection uses convenience sampling method, with a total sample size of 89. The data analysis model used is multiple linear regression. The results of this study indicate that internal control and good governance affect the performance of employees in the financial department, while the use of information technology does not affect the performance of employees in the financial department. The value of $R^{2}$ or the coefficient of determination is 0.256 which means that the variation or change in the dependent variable can only be explained by the variation of the three independent variables amounting to $25.6 \%$, while $75.4 \%$ is influenced by other factors.
\end{abstract}

Keywords: Internal Control, Good governance, Use of Information Technology, Employee Performance.

ABSTRAK

Penelitian ini bertujuan untuk menguji dan mendapatkan bukti empiris pengaruh pengendalian internal, good governance dan pemanfaatan teknologi informasi terhadap kinerja pegawai pada bagian keuangan pada SKPD di Kabupaten Indragiri Hilir. Populasi dalam penelitian ini adalah pegawai bagian keuangan pada SKPD di Kabupaten Indragiri Hilir. Pemilihan sampel menggunakan convenience sampling method, dengan jumlah sampel sebanyak 89. Model analisis data yang digunakan adalah regresi linear berganda. Hasil penelitian ini menunjukan bahwa pengendalian internal dan good governance berpengaruh terhadap kinerja pegawai pada bagian keuangan, sedangkan pemanfaatan teknologi informasi tidak berpengaruh terhadap kinerja pegawai pada bagian keuangan. Nilai $\mathrm{R}^{2}$ atau nilai koefisiensi determinasi sebesar 0,256 yang berarti variasi atau perubahan variabel dependen hanya mampu dijelaskan oleh variasi dari ketiga variabel independen adalah sebesar $25,6 \%$, sedangkan 75,4 \% dipengaruhi oleh faktor- faktor lain

Kata Kunci: Pengendalian Internal, Good governance, Pemanfaatan Teknologi Informasi dan Kinerja Pegawai.

\section{PENDAHULUAN}

\subsection{Latar Belakang Masalah}

Faktor yang sangat mempengaruhi keberhasilan instansi pemerintahan adalah para pegawai yang memiliki kemampuan yang kompeten karena pegawai merupakan pelaku mulai dari perencanaan awal hingga mengevaluasi hasil kerja yang telah direncanakan. Akantetapi, masih banyak pegawai di kabupaten Indragiri Hilir dengan penempatan posisi yang tidak sesuai bidang keahlian dimana pegawai yang ditempatkan dibidang akuntansi dan pelaporan tidak berlatar belakang pendidikan formal akuntansi sehingga memungkinkan terjadinya kesalahan dalam pencatatan dan pelaporan yang telah dibuat. Penilaian kinerja pada instansi pemerintah sangat penting untuk dilakukan, agar dapat meningkatkan kualitas pelayanan terhadap masyarakat. Selain itu, penilaian kinerja pada instansi pemerintah digunakan sebagai alat untuk mengevaluasi kinerja pada periode yang lalu, untuk digunakan sebagaidasar penyusunan strategi organisasi selanjutnya.

Kinerja organisasi bagian keuangan pada dasarnya dilakukan untuk menilai kinerja dimasa lalu dengan melakukan berbagai analisis sehingga diperoleh posisi keuangan yang mewakili realitas entitas dan potensi-potensi kinerja bagian keuangan dapat dilihat dari laporan keuangan pada isntansi tersebut. Maka dari itu pengendalian internal sangat dibutuhkan dalam suatu instansi pemerintahan. Pengendalian internal merupakan cara untuk mengarahkan, mengawasi dan mengukur sumber daya disuatu organisasi.

Selain pengendalian internal, good governance (tata kelola pemerintahan yang baik) sangat di perlukan dalam suatu intansi pemerintahan karena good governance adalah suatu penyelenggara manajemen yang solit dan bertanggung jawab yang sejalan dengan prinsip demokrasi dan pasar yang efesien. Good governance digunakan sebagai alat ukur untuk menilai kinerja pegawai dan organisasi pemerintah, yang lebih menekankan pada aspek transparansi, akuntabel, serta kesejahteraan masyarakat dan pelayanan publik yang ekonomis, efektif, dan efisien (Kartika, 2012). Jika di suatu instansi pemerintahan khususnya pegawai bidang keuangan telah menerapkan good governance dengan baik maka informasi keuangan akan dihasilkan dengan baik, transparansi dan akuntabilitas. 
Kinerja organisasi juga sangat dipengaruhi oleh penguasaan teknologi informasi dari karyawan suatu organisasi. Dengan aplikasi teknologi, maka organisasi akan mengalami perubahan sistem manajemen, dari sistem tradisional ke sistem manajemen kontemporer. Teknologi informasi berkaitan dengan pelayanan, hal tersebut dikarenakan salah satu dimensi dari kualitas pelayanan adalah kecepatan pelayanan dimana dimensi tersebut dapat dikaitkan dengan teknologi informasi. Adanya teknologi informasi maka pelayanan yang diberikan khususnya pada organisasi jasa, akan semakin cepat dan akurat.

Pemanfaatan teknologi informasi menurut Wijana (2007) dalam Suciani (2016) merupakan manfaat yang diharapkan oleh pengguna sistem informasi dalam melaksanakan tugasnya atau perilaku dalam menggunakan teknologi pada saat melakukan pekerjaan. Teknologi informasi (TI) telah menjadi bagian penting dalam organisasi dimana infrastruktur teknologi informasi tersebut memungkinkan para pegawai untuk berkomunikasi dan melakukan transaksi dengan perangkat kerja lain yang berhubungan dengan kerjanya. Namun mengimplemetasikan teknologi informasi tidaklah murah dimana kendala penerapan teknologi informasi antara lain berkaitan dengan kondisi perangkat keras dan perangkat lunak yang digunakan pemutakhiran data, dan keterbatasan dana. Kendala ini menjadi faktor pemanfaatan teknologi informasi dalam organisasi belum optimal.

Hasil penelitian sebelumnya menunjukan bahwa good governance dan pemanfaatan teknologi informasi berpengaruh positif terhadap terhadap kinerja pegawai, sehingga peneliti tertarik untuk meneliti kembali dengan mengembangkan penelitian Rini (2014). Alasan penelitian ini dilakukan pada SKPD di Kabupaten Indragiri Hilir adalah karena peneliti ingin melihat apakah pengendalian internal, good governance dan pemanfaatan teknologi informasi pada dinas - dinas yang ada di Indragiri Hilir sudah berjalan dengan efektif sehingga tidak menimbulkan keterlambatan dalam memberikan pelayanan terhadap masyarakat. Berdasarkan penjelasan diatas maka peneliti tertarik untuk melakukan penelitian dengan judul "Pengaruh Pengendalian Internal, Good governance Dan Pemanfaatan Teknologi Informasi Terhadap Kinerja Pegawai Bagian Keuangan Pada SKPD di Kabupaten Indragiri Hilir”.

\subsection{Perumusan Masalah}

Berdasarkan latar belakang yang telah dikemukanan di atas, maka perumusan masalah dalam penelitian ini adalah:

1. Apakah pengendalian intern berpengaruh pada kinerja pegawai bagian keuangan pada SKPD di Kabupaten Indragiri Hilir?

2. Apakah good governance berpengaruh terhadap kinerja pegawai bagian keuangan pada SKPD di Kabupaten Indragiri Hilir?

3. Apakah pemanfaatan teknologi informasi berpengaruh terhadap kinerja pegawai bagian keuangan pada SKPD di Kabupaten Indragiri Hilir?

4. Apakah pengendalian internal, good governance dan pemanfaatan teknologi informasi berpengaruh secara simultan terhadap kinerja karyawan bagian keuangan pada SKPD di Kabupaten Indragiri Hilir?

\section{TINJAUAN PUSTAKA}

\subsection{Pengendalian Internal}

Menurut Hery (2014) pengendalian internal adalah seperangkat kebijakan dan prosedur untuk melindungi aset atau kekayaan perusahaan dari segala tindakan penyalahgunaan, menjamin tersedianya informasi akuntansi perusahaan yang akurat, serta memastikan bahwa semua ketentuan (peraturan) hukum atau undang-undang serta kebijakan manajemen telah dipatuhi atau dijalankan sebagaimana mestinya oleh seluruh karyawan perusahaan. Ketentuan tersebut meliputi kebijakan dibidang pajak, pasar modal, hukum bisnis, undang-undang anti-korupsi, dan sebagainya .

Demikian juga pengendalian internal dilakukan untuk memantau apakah kegiatan operasional maupun finansial perusahaan telah berjalan sesuai prosedur dan kebijakan yang telah ditetapkan oleh manajemen. Adanya penerapan sistem pengendalian internal secara ketat, diharapkan seluruh kegiatan operasional perusahaan dapat berjalan dengan baik menuju tercapainya maksimalisis profit. Bahkan tidak hanya dari segi operasional perusahaan juga dapat termonitor dengan baik. Pada dasarnya faktor efesiensi dan efektivitas unit/perusahaan merupakan dua hal yang juga merupakan sasaran yang diterapkannya pengendalian internal, karena apabila pengendalian internal tidak berjalan sebagaimana yang diharapkan maka kemungkinan besar (hampir dipastikan) akan timbul namanya inefisiensi (pemborosan sumber daya), yang pada akhirnya akan membebani tingkat profitabilitas (keuntungan perusahaan).

PP Nomor 60 Tahun 2008, bahwa Sistem Pengendalian Internal Pemerintah Daerah (SPIP) merupakan proses integral pada tindakan dan kegiatan yang dilakukan secara terus-menerus oleh pimpinan dan seluruh pegawai untuk memberikan keyakinan yang memadai atas tercapainya tujuan organisasi melalui kegiatan yang efektif dan efisien, keandalan pada laporan keuangan, pengamananaset negara, dan ketaatan terhadap peraturan perundang-undangan (Pangestika, 2016)

Sistem Pengendalian Internal Pemerintah ini merupakan sistem pengendalian internal yang diimplementasikan secara menyeluruh di lingkungan pemerintah pusat dan daerah. American Institute of Certified Public Accountants (AICPA) menyebutkan bahwa sistem pengendalian internal meliputi struktur organisasi, semua metode dan ketentuan yang terkoordinasi dalam instansi untuk melindungi harta kekayaan 
instansi, memeriksa ketelitian dan seberapa jauh data akuntansi dapat dipercaya, guna meningkatkan efisiensi dan mendorong ditaatinya kebijakan organisasi yang telah diterapkan. SPIP bertujuan untuk memberikan keyakinan yang memadai terkait empat hal, yaitu :

1. Tercapainya efektivitas dan efisiensi pencapaian tujuan

2. Keandalan pelaporan keuangan

3. Pengamatan aset negara

4. Ketaatan terhadap peraturan perundang-undangan

\subsection{Good governance}

Kartika, dkk (2012) mendefinisikan good governanace sebagai penyelenggaran pemerintahan yamg baik. Good governanace adalah dasar, syarat dan landasan untuk pengolahan lingkungan hidup yang baik. Good governanace dikatakan baik apabila mengikuti kaidah-kaidah tertentu sesuai dengan prinsip-psrinsip dasar good governanace. Sedangkan menurut Santosa (2006) dalam Akadun (2009), sebuah governance dikatakan baik (good) apabila sumber daya dan masalah-masalah publik dikelola secara efektif dan efesien yang merupakan respon kebutuhan terhadap masyarakat.

Munculnya konsep good governance di Indonesia sebagai reaksi atas prilaku pengelola perusahaan yang tidak memperhitungkan stakholder-nya. Hal ini terlihat jelas ketika krisis terjadi di Indonesia sejak tahun 1997. Krisis tersebut memberi pelajaran berharga bahwa pembangunan yang dilaksanakan selama ini ternyata tidak didukung struktur ekonomi yang kokoh. Hampir semua perusahaan besar menjalankan roda bisnis dengan manajemen yang tidak baik dan sarat praktek korupsi.

Untuk mewujudkan good public and corporate governance dalam rangka menciptakan kesejateraan masyarakat, maka diperlukan serangkaian reformasi di sektor publik. Dimensi reformasi sektor publik tersebut tidak saja sekedar perubahan format lembaga, akan tetapi mencakup pembaharuan alat-alat yang digunakan untuk mendukung berjalannya lembaga-lembaga publik tersebut secara ekonomis, efesien, efektif, transparansi, dana akuntabel, untuk mewujudkan good governance yang diperlukan reformasi kelembagaan (institutional reform). Reformasi kelembagaan menyangkut pembenahan seluruh alat-alat pemerintahan baik struktur maupun infrastrukturnya. Menurut Mardiasmo (2009) selain reformasi kelembagaan dan reformasi manajemen sektor publik, untuk terciptanya good governance diperlukan serangkaian reformasi lanjutan terutama yang terkait dengan sistem pengelolaan keungan pemerintahan daerah yaitu:

1. Reformasi sitem penganggaran (budgeting reform)

2. Reformasi sistem akuntansi (accounting reform)

3. Reformasi sistem pemeriksaaan (audit reform) dan

4. Reformasi sistem manajemen keuangan daerah (financial management reform)

Mardiasmo (2009) menyebutkan tiga karakteristik utama good governance yang dapat dijadikan sebagai indikator dalam sektor publik tersebut adalah sebagai berikut :

1. Transparansi, diartikan sebagai keterbukaan lembagalembaga sektor publik dalam memberikan informasi dan disclosure (penyingkapan) kepada masyarakat mengenai kinerja pemerintahan.

2. Akuntabilitas Publik, sebagai bentuk kewajiban mempertanggungjawabkan keberhasilan atau kegagalan pelasanaan misi organisasi dalam mencapai tujuan dan sasaran yang telah ditetapkan sebelumnya.

3. Value for Money, merupakan konsep pengelolaan organisasi sektor publik yang mendasarkan pada tiga elemen utama, yaitu ekonomis, efisiensi, dan efektivitas.

\subsection{Pemanfaatan Teknologi Informasi}

Menurut Rerung (2018), teknologi informasi adalah pengguna peralatan elektronika terutama komputer untuk menyimpan, menganalisis, dan mendistribusikan informasi apa saja termasuk kata, bilangan, dan gambar. Sedangkan menurut Indrajit (2016), teknologi informasi adalah suatu teknologi yang berhubungan dengan pengolahan data menjadi informasi dan proses penyaluran data/ informasi tersebut dalam batas-batas ruang dan waktu.

Menurut Rini (2014) berikut ini adalah beberapa penggunaan teknologi informasi untuk pemerintahan.

1. Menghasilkan produk atau servis teknologi informasi.

Di Indonesia banyak progremer yang kreatif akan tetapi sayangnya belum menemukan saluran yang pas.

2. Teknologi informasi untuk pelayanan Menggunakan teknologi informasi untuk meningkatkan pelayanan kepada masyarakat dengan memperbesar pelayanan melalui internet.

3. Kualitas pelayanan

Hal yang paling dituntut publik saat ini adalah masalah kualitas pelayanan dari kantor-kantor pemerintah. Dengan menggunakan teknologi informasi, aparatur pemerintah lebih mudah dalam mencari informasi yang akan membantu meningkatkan produknya.

4. Meningkatkan kinerja

Teknologi informasi dapat untuk meningkatkan kinerja istitusi untuk pemerintahan. 
Khusus pemerintahan, penciptaan sistem kerja atau tata kerja dengan sistem E-government sudah menjadi suatu kebutuhan. E-government mengacu pada penggunaan teknologi informasi oleh pemerintahan, seperti menggunakan internet yang mempunyai kemampuan menghubungkan keperluan penduduk, bisnis, dan kegiatan lainnya. Menurut Rerung (2018) manfaat E-government yang dapat dirasakan antara lain :

1. Pelayanan yang lebih baik kepada masyarakat.

2. Peningkatan hubungan antara pemerintah, pelaku bisnis dan masyarakat umum.

3. Pemberdayaan masyarakat melalui informasi yang mudah diperoleh .

4. Pelaksanaan pemerintahan yang lebih efisien.

\subsection{Kinerja Pegawai}

Menurut Azlina dan Amelia dalam Mangkunegara (2016) bahwa istilah kinerja berasal dari kata job performance atau actual performance (prestasi kerja atau prestasi sesungguhnya yang dicapai seseorang) yaitu hasil kerja secara kualitas dan kuantitas yang dicapai oleh seorang pegawai dalam melaksanakan tugasnya sesuai dengan tanggung jawab yang diberikan kepadanya. Kinerja pegawai dapat diartikan sebagai gambaran atas pencapaian segala aktivitas yang dilakukan oleh pegawai dalam mewujudkan sasaran, tujuan, visi, dan misi instansi. Kinerja pegawai merupakan landasan yang kuat bagi organisasi untuk mencapai tujuan organisasi. Semakin tinggi kinerja pegawai maka akan semakin tinggi kinerja organisasi.

Menurut Budiharjo (2015) penilaian kinerja pegawai/karyawan perlu dilakukan secara rutin, periodik, dan terprogram. Hal ini membuat para pengendali sumber daya manusia (SDM), dituntut untuk dapat memiliki kemampuan dan merumuskan rencana pengembangan SDM yang berkualitas. Menurut Budiharjo (2015) penilaian kinerja terhadap kinerja pegawai, harus memperhatikan lima faktor penilaian kinerja yaitu sebagai berikut:

1. Kualitas yang dihasilkan oleh karyawan dapat diminati dari.

a. Akurasi

b. Ketelitian.

c. Penampilan dan

d. Peneriamaan keluaran.

2. Kualitas yang dihasilkan oleh karyawan yang dapat dilihat dari.

a. Volume.

b. Keluaran dan kontribusi bagi pencapaian target.

3. Supervise yang dilakukan oleh pimpinan dalam bentuk.
a. Saran.
b. Araha dan
c. Perbaikan

4. Kehadiran atau kedisiplinan karyawan dapat dilihat dari
a. Regulasi.
b. Tingkat kendala dan
c. Ketepatan waktu dan kerja.

\subsection{Kerangka Pemikiran}

Gambar 2.1

\section{Kerangka pemikiran}

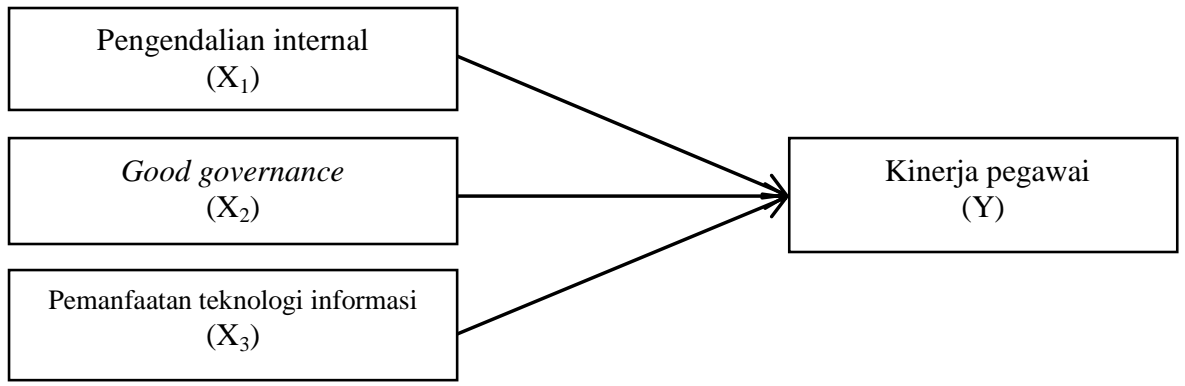

Variabel Independen

Variabel Dependen

\subsection{Hipotesa} berikut:

Berdasarkan uraian teoritis dan kerangka pemikiran diatas, maka dirumuskan hipotesa sebagai

$\mathrm{H}_{1}$ : Pengendalian internal berpengaruh terhadap kinerja pegawai bagian keuangan pada SKPD di Kabupaten Indragiri Hilir

$\mathrm{H}_{2}$ : Good governance berpengaruh terhadap kinerja pegawai bagian keuangan.pada SKPD di Kabupaten Indragiri Hilir.

Herda Nengsy - R. Desi Karlina, Pengaruh Pengendalian Internal, Good governance Dan Pemanfaatan Teknologi Informasi Terhadap Kinerja Pegawai Bagian Keuangan pada SKPD di Kabupaten Indragiri Hilir 
$\mathrm{H}_{3}$ : Pemanfaatan teknologi informasi berpengaruh terhadap kinerja pegawai bagian keuangan pada SKPD di Kabupaten Indragiri Hilir.

$\mathrm{H}_{4}$ : Pengendalian internal, good governance dan pemanfaatan teknologi informasi berpengaruh terhadap kinerja pegawai bagian keuangan pada SKPD di Kabupaten Indragiri Hilir

\section{METODOLOGI PENELITIAN}

\subsection{Tempat dan Waktu}

Penelitian ini dilakukan pada SKPD di Kabupaten Indragiri Hilir dengan waktu yang digunakan untuk melakukan penelitian ini selama 3 bulan yaitu dari bulan Januari sampai dengan Maret 2020

\subsection{Populasi dan Sampel}

Populasi adalah wilayah generalisasi yang terdiri atas obyek/objek yang mempunyai kualitas dan karakteristik tertentu yang ditetapkan oleh penliti untuk dipelajari dan kemudian ditarik kesimpulannya (Sugiyono, 2013). Populasi dalam penelitian ini adalah seluruh pegawai bagian keuangan pada 31 satuan kerja perangkat daerah kabupaten Indragiri Hilir. Daftar SKPD yang menjadi populasi dalam penelitian ini tersaji pada tabel berikut :

Tabel 3.1

Daftar SKPD

\begin{tabular}{|c|l|}
\hline No. & \multicolumn{1}{|c|}{ Satuan Kerja Perangkat Daerah (SKPD) } \\
\hline 1 & Sekretariat DPRD \\
\hline 2 & Inspektorat Daerah \\
\hline 3 & Badan perencanaan pembangunan daerah \\
\hline 4 & Badan keuangan dan asset daerah \\
\hline 5 & Badan pendapatan daerah \\
\hline 6 & Badan kepegawaian dan pengembangan sumber daya manusia \\
\hline 7 & Badan kesatuan bangsa dan politik \\
\hline 8 & Badan penanggulangan bencana daerah \\
\hline 9 & Dinas pendidikan \\
\hline 10 & Dinas kesehatan \\
\hline 11 & Dinas pekerjaan umum dan penataan ruang \\
\hline 12 & Dinas perumahan rakyat dan kawasan permukiman \\
\hline 13 & Dinas pemadam kebakaran dan penyelamat \\
\hline 14 & Dinas sosial \\
\hline 15 & Dinas tenaga kerja dan transmigrasi \\
\hline 16 & Dinas pengendalian penduduk,keluarga berencana dan pemberdayaan \\
\hline & perempuan dan perlindungan anak \\
\hline 17 & Dinas pangan,tanaman pangan,hortikultura dan peternakan \\
\hline 18 & Dinas lingkungan hidup dan kebersihan \\
\hline 19 & Dinas kependudukan dan pencatatan sipil \\
\hline 20 & Dinas pemberdayaan masyarakat dan desa \\
\hline 21 & Dinas perhubungan \\
\hline 22 & Dinas komunikasi,informatika, persediaan dan statistic \\
\hline 23 & Dinas koperasi, usaha kecil menengah \\
\hline 24 & Dinas penanaman modal dan pelayanan terpadu satu pintu \\
\hline 25 & Dinas pariwisata,kepemudaan, olahraga dan budaya \\
\hline 26 & Dinas perpustakaan dan kearsipan \\
\hline 27 & Dinas perikanan \\
\hline 28 & Dinas perkebunan \\
\hline 29 & Dinas perdagangan dan perindustrian \\
\hline 30 & Satuan polisi pamongpraja \\
\hline 31 & Sekretariat Daerah \\
\hline & Inspekt Kabupan Indragri Hir (2019) \\
\hline
\end{tabular}

Sumber: Inspektorat Kabupaten Indragiri Hilir (2019)

Sampel adalah bagian dari jumlah dan karakteristik yang dimiliki oleh populasi tersebut (Sugiyono, 2013). Metode pengambilaan sampel dalam penelitian ini adalah convenience sampling method, yaitu metode pengambilan contoh sampel dari elemen populasi (orang atau kejadian) yang datanya mudah diperoleh.

\subsection{Prosedur Dan Pengumpulan Data}

Pengumpulan data dilakukan dengan metode kuesioner. Data penelitian ini berupa data primer yang dikumpulkan menggunakan kuesioner yang dibagikan secara langsung kepada responden yaitu pegawai bagian keuangan pada SKPD di Kabupaten Indragiri Hilir. 


\subsection{Definisi Operasional Dan Pengukuran Variabel}

\subsubsection{Variabel Independen}

\section{Pengendalian Internal $\left(\mathbf{X}_{1}\right)$}

Menurut Hery (2014) pengendalian internal adalah seperangkat kebijakan dan prosedur untuk melindungi aset atau kekayaan perusahaan dari segala tindakan penyalahgunaan, manjamin tersedianya informasi akuntansi perusahaan yang akurat, serta memastikan bahwa semua ketentuan (peraturan) hukum/ undang-undang serta kebijakan manajemen telah dipatuhi atau dijalankan sebagaimana mestinya oleh seluruh karyawan perusahaan.

Variabel pengendalian internal diukur dengan menggunakan 5 indikator yaitu lingkungan pengendalian, penilaian risiko, kegiatan pengendalian, informasi dan komunikasi, pemantauan pengendalian intern dengan 20 item pertanyaan yang telah dikembangkan oleh Pangestika (2016) dan menggunakan 5 skala Likert

\section{Good governance $\left(\mathrm{X}_{2}\right)$}

Menurut Mardiasmo (2009) good governance sering diartikan sebagai keperintahan yang baik. Variabel good governance diukur dengan menggunakan 3 indikator yaitu, transparansi, akuntabilitas publik, value of money dengan 17 item pertanyaan yang telah dikembangkan oleh Pangetika (2016) dengan menggunakan 5 skala Likert.

\section{Pemanfaatan Teknologi Informasi $\left(\mathbf{X}_{3}\right)$}

Teknologi informasi dapat dimaksud sebagai kegiatan pengumpulan pengolahan, penyimpanan, penyebaran dan pemanfaatan suatu informasi. Selain menyangkut perangkat keras (hardware) dan perangkat lunak (software) ini juga memperhatikan kepentingan manusia dan manfaatnya.

Variabel pemanfaatan teknologi informasi diukur dengan menggunakan 5 indikator yaitu, sistem akuntansi sesuai SAP, jaringan internet, jaringan internet termanfaatkan dengan baik, aplikasi yang digunakan, laporan keuangan terkomputerisasi. Pada variabel pemanfaatan teknologi informasi ini menggunakan 6 item pertanyaan yang telah dikembangkan oleh Rini (2014), dengan menggunakan 5 skala Likert.

\subsubsection{Variabel Dependen}

\section{Kinerja Pegawai (Y)}

Menurut Azlina dan Amelia dalam Mangkunegara (2015) bahwa istilah kinerja berasal dari kata job performance atau actual performance (prestasi kerja atau prestasi sesungguhnya yang dicapai seseorang) yaitu hasil kerja secara kualitas dan kuantitas yang dicapai oleh seorang pegawai dalam melaksanakan tugasnya sesuai dengan tanggung jawab yang diberikan kepadanya.

Variabel kinerja pegawai diukur dengan menggunakan 5 indikator yaitu, kualitas, kuantitas, ketepatan waktu, efektifitas. Pada variabel pemanfaatan teknologi informasi ini menggunakan 16 item pertanyaan yang telah dikembangkan oleh Pangestika (2016), dengan menggunakan 5 skala Likert.

\subsection{Teknik Analisa Data}

Metode yang digunakan dalam penelitian ini adalah teknik analisis regresi berganda. Tujuan dari analisa data adalah untuk mendapatkan informasi relevan yang terkandung dalam data tersebut dan menggunakan hasilnya untuk memecahkan suatu masalah (Ghozali, 2011). Analisis data dengan menggunakan program SPSS (Statistical Product And Service Solution) versi 24,0 yang merupakan salah satu aplikasi computer untuk menganalisis data statistik.

\section{HASIL PENELITIAN DAN PEMBAHASAN}

\subsection{Gambaran Umum Objek Penelitian}

Objek penelitian pada penelitian ini adalah Satuan Kerja Perangkat Daerah (SKPD) dilingkungan pemerintahan di Kabupaten Indragiri Hilir Provinsi Riau. 31 sampel disebarkan sebanyak 93 kuesioner dan kuesioner yang kembali sebanyak 89 kuesioner. Penelitian ini juga dilakukan selama kurang lebih 3 bulan, dimana penelitian ini ditujukan pada karyawan bagian keuangan. Pengambilan sample yang dilakukan adalah dengan convenience sampling yaitu pengambilan sampel yang datanya mudah diperoleh.

Berikut adalah gambaran kuesioner yang sudah di sebarkan dan tingkat pengembalian kuesioner yang dikembalikan oleh responden :

Tabel 4.1

Tingkat Pengembalian Kuesioner

\begin{tabular}{|l|c|}
\hline \multicolumn{1}{|c|}{ Keterangan } & Jumlah \\
\hline Jumlah kuesioner yang disebar & 93 \\
\hline Jumlah kuesioner yang tidak dapat diolah & 4 \\
\hline Jumlah kuesioner yang dapat diolah & 89 \\
\hline Tingkat pengembalian & $\mathbf{9 6 \%}$ \\
\hline
\end{tabular}

Sumber :Data diolah, 2020

Herda Nengsy - R. Desi Karlina, Pengaruh Pengendalian Internal, Good governance Dan Pemanfaatan Teknologi Informasi Terhadap Kinerja Pegawai Bagian Keuangan pada SKPD di Kabupaten Indragiri Hilir 


\subsection{Hasil Penelitian}

\subsubsection{Hasil Statistik Deskriptif}

Analisa deskriptif bertujuan agar peneliti mendapatkan gambaran mengenai tedensi/kecendrungan jawaban responden mengenai variabel-variabel penelitian yang digunakan. Berikut ini diuraikan hasil analisis deskriptif pada masing - masing variabel penelitian.

Tabel 4.2

Hasil Analisis Deskriptif

Descriptive Statistics

\begin{tabular}{|c|c|c|c|c|c|c|}
\hline & $\mathrm{N}$ & Minimum & Maximum & Mean & Std. Deviation & Variance \\
\hline Pengendalian Internal & 89 & 62 & 88 & 74.89 & 5.767 & 33.260 \\
\hline Good Governance & 89 & 54 & 82 & 67.36 & 6.493 & 42.165 \\
\hline Pemanfaatan Tekologi informasi & 89 & 16 & 30 & 23.15 & 2.699 & 7.285 \\
\hline Kinerja Pegawai & 89 & 42 & 64 & 54.33 & 6.550 & 42.904 \\
\hline
\end{tabular}

Valid N (listwise)

Sumber : Data Diolah SPSS 26, 2020

Berdasarkan tabel 4.2 dalam statistik deskriptif dari variabel-variabel yang digunakan menunjukkan rata-rata variabel pengendalian internal 74.89 dengan standar deviasinya 5.767. Rata- rata variabel good governance 67.36 dengan standar deviasinya 6.493. Rata-rata variabel pemanfaatan teknologi informasi 23.15 dengan standar deviasinya 2.669. Rata-rata variabel kinerja pegawai bagian keuangan 54.33 dengan standar deviasinya 6.550. Adapun hasil maksimum untuk variabel pengendalian internal adalah 88 dengan hasil minimum 62. Maksimum untuk variabel good governance adalah 82 dengan hasil minimum 54. Maksimum untuk variabel pemanfaatan teknologi informasi adalah 30 dengan minimum 16, dan maksimum variabel kinerja pegawai bagian keuangan adalah 64 dengan hasil minimum 42.

\subsubsection{Hasil Uji Kualitas Data}

\subsubsection{Uji Validitas}

Uji validitas dilakukan untuk mengetahui valid tidaknya pertanyaan-pertanyaan yang digunaka dalam kuesioner (Sugiyono, 2013). Untuk mengetahui apakah pertanyaan valid atau tidak, dapat dilakukan dengan membandingkan rhitung dengan $r$ tabeluntuk degree of freedom $(d f)=n-2$ dalam hal ini adalah jumlah sampel. Pada penelitian ini $\mathrm{n}$ adalah jumlah sampel. Dalam penelitian ini sampel berjumlah 89 sampel sehingga dapat dihitung besarnya df pada penelitian ini sebesar $\mathrm{df}=89-2$. Maka diperoleh $\mathrm{r}$ tabel sebesar 0,208 $(\alpha=5 \%)$. Adapun uji validitas untuk variabel pengendalian internal dapat dilihat pada tabel bertikut :

\section{Tabel 4.3}

Hasil Uji Validitas Variabel Pengendalian Internal

\begin{tabular}{|c|c|c|c|}
\hline Pertanyaan & r Hitung & r Tabel & Keterangan \\
\hline Pertanyaan 1 & 0,311 & 0,208 & Valid \\
\hline Pertanyaan 2 & 0,547 & 0,208 & Valid \\
\hline Pertanyaan 3 & 0,422 & 0,208 & Valid \\
\hline Pertanyaan 4 & 0,267 & 0,208 & Valid \\
\hline Pertanyaan 5 & 0,308 & 0,208 & Valid \\
\hline Pertanyaan 6 & 0,455 & 0,208 & Valid \\
\hline Pertanyaan 7 & 0,430 & 0,208 & Valid \\
\hline Pertanyaan 8 & 0,507 & 0,208 & Valid \\
\hline Pertanyaan 9 & 0,532 & 0,208 & Valid \\
\hline Pertanyaan 10 & 0,582 & 0,208 & Valid \\
\hline Pertanyaan 11 & 0,346 & 0,208 & Valid \\
\hline Pertanyaan 12 & 0,520 & 0,208 & Valid \\
\hline Pertanyaan 13 & 0,380 & 0,208 & Valid \\
\hline Pertanyaan 14 & 0,538 & 0,208 & Valid \\
\hline Pertanyaan 15 & 0,605 & 0,208 & Valid \\
\hline Pertanyaan 16 & 0,544 & 0,208 & Valid \\
\hline Pertanyaan 17 & 0,613 & 0,208 & Valid \\
\hline Pertanyaan 18 & 0,503 & 0,208 & Valid \\
\hline Pertanyaan 19 & 0,505 & 0,208 & 0,208 \\
\hline Pertanyaan 20 & 0,613 & & \\
\hline
\end{tabular}

Sumber : Data Diolah SPSS 26, 2020

Berdasarkan tabel 4.3 diatas, pengujian validitas instrumen penelitian (kuesioner) dengan 20 pertanyaan untuk variabel pengendalian internal mendapatkan nilai $r$ hitung $\geq r$ tabel yang mana $r$ tabel dari 89 responden adalah 0,208 dan $\mathrm{P} \leq 0,05$, sehingga keseluruhan instrumen penelitian tersebut dinyatakan valid. 
Adapun uji validitas variabel good governance dapat dilihat dari tabel berikut :

Tabel 4.4

Hasil Uji Validitas Variabel good governance

\begin{tabular}{|c|c|c|c|}
\hline Pertanyaan & r Hitung & r Tabel & Keterangan \\
\hline Pertanyaan 1 & 0,520 & 0,208 & Valid \\
\hline Pertanyaan 2 & 0,658 & 0,208 & Valid \\
\hline Pertanyaan 3 & 0,616 & 0,208 & Valid \\
\hline Pertanyaan 4 & 0,534 & 0,208 & Valid \\
\hline Pertanyaan 5 & 0,662 & 0,208 & Valid \\
\hline Pertanyaan 6 & 0,581 & 0,208 & Valid \\
\hline Pertanyaan 7 & 0,694 & 0,208 & Valid \\
\hline Pertanyaan 8 & 0,639 & 0,208 & Valid \\
\hline Pertanyaan 9 & 0,566 & 0,208 & Valid \\
\hline Pertanyaan 10 & 0,639 & 0,208 & Valid \\
\hline Pertanyaan 11 & 0,668 & 0,208 & Valid \\
\hline Pertanyaan 12 & 0,760 & 0,208 & Valid \\
\hline Pertanyaan 13 & 0,689 & 0,208 & Valid \\
\hline Pertanyaan 14 & 0,225 & 0,208 & Valid \\
\hline Pertanyaan 15 & 0,225 & 0,208 & Valid \\
\hline Pertanyaan 16 & 0,689 & 0,208 & 0,208 \\
\hline Pertanyaan 17 & 0,242 & & \\
\end{tabular}

Sumber : Data Diolah SPSS 26, 2020

Berdasarkan tabel 4.4 diatas, pengujian validitas instrumen penelitian (kuesioner) dengan 17 pertanyaan untuk variabel Good governance mendapatkan nilai nilai $r$ hitung $\geq r$ tabel yang mana $r$ tabel dari 89 responden adalah 0,208 dan $\mathrm{P} \leq 0,05$, sehingga keseluruhan instrumen penelitian tersebut dinyatakan valid.

Adapun uji validitas variabel pemanfaatan teknologi informasi dapat dilihat dari tabel berikut :

Tabel 4.5

Hasil Uji Validitas Variabel Pemanfaatan Teknologi Informasi

\begin{tabular}{|c|c|c|c|}
\hline Pertanyaan & r Hitung & r Tabel & Keterangan \\
\hline Pertanyaan 1 & 0,529 & 0,208 & Valid \\
\hline Pertanyaan 2 & 0,790 & 0,208 & Valid \\
\hline Pertanyaan 3 & 0,708 & 0,208 & Valid \\
\hline Pertanyaan 4 & 0,678 & 0,208 & Valid \\
\hline Pertanyaan 5 & 0,522 & 0,208 & Valid \\
\hline Pertanyaan 6 & 0,714 & 0,208 & Valid \\
\hline
\end{tabular}

Sumber : Data Diolah SPSS 26, 2020

Berdasarkan tabel 4.5 diatas, pengujian validitas instrumen penelitian (kuesioner) dengan 6 pertanyaan untuk variabel good governance mendapatkan nilai nilai $r$ hitung $\geq r$ tabel yang mana $r$ tabel dari 89 responden adalah 0,208 dan $\mathrm{P} \leq 0,05$, sehingga keseluruhan instrumen penelitian tersebut dinyatakan valid.

Adapun uji validitas variabel kinerja pegawai bagian keuangan dapat dilihat dari tabel berikut :

Tabel 4.6

Hasil Uji Validitas Variabel Kinerja Pegawai Bagian Keuangan

\begin{tabular}{|c|c|c|c|}
\hline Pertanyaan & r Hitung & r Tabel & Keterangan \\
\hline Pertanyaan 1 & 0,539 & 0,208 & Valid \\
\hline Pertanyaan 2 & 0,895 & 0,208 & Valid \\
\hline Pertanyaan 3 & 0,682 & 0,208 & Valid \\
\hline Pertanyaan 4 & 0,435 & 0,208 & Valid \\
\hline Pertanyaan 5 & 0,685 & 0,208 & Valid \\
\hline Pertanyaan 6 & 0,895 & 0,208 & Valid \\
\hline Pertanyaan 7 & 0,450 & 0,208 & Valid \\
\hline Pertanyaan 8 & 0,895 & 0,208 & Valid \\
\hline Pertanyaan 9 & 0,536 & 0,208 & Valid \\
\hline Pertanyaan 10 & 0,461 & 0,208 & Valid \\
\hline Pertanyaan 11 & 0,794 & 0,208 & Valid \\
\hline Pertanyaan 12 & 0,622 & 0,208 & Valid \\
\hline Pertanyaan 13 & 0,461 & 0,208 & Valid \\
\hline Pertanyaan 14 & 0,495 & 0,208 & Valid \\
\hline Pertanyaan 15 & 0,344 & 0,208 & 0,208 \\
\hline Pertanyaan 16 & 0,579 & & \\
\hline
\end{tabular}

Sumber : Data Diolah SPSS 26,2020

Berdasarkan tabel 4.6 diatas, pengujian validitas instrumen penelitian (kuesioner) dengan 16 pertanyaan untuk variabel kinerja pegawai mendapatkan nilai nilai $r$ hitung $\geq \mathrm{r}$ tabel yang mana $\mathrm{r}$ tabeldari 89 responden adalah 0,208 dan $\mathrm{P} \leq 0,05$, sehingga keseluruhan instrumen penelitian tersebut dinyatakan valid

Herda Nengsy - R. Desi Karlina, Pengaruh Pengendalian Internal, Good governance Dan Pemanfaatan Teknologi Informasi Terhadap Kinerja Pegawai Bagian Keuangan pada SKPD di Kabupaten Indragiri Hilir 


\subsubsection{Uji reabilitas}

Uji reabilitas diguanakan untuk mengukur suatu kuesioner yang merupakan indikator dari variabel atau kontruk. Instrumen dikatakan reliabel jika nilai Cronbach's Alpa> 0,60 (Ghozali, 2011). Hasil uji reliabelitas masing-masing variabel penelitian ini dilihat pada tabel berikut:

Tabel 4.7

Hasil Uji Reabilitas

\begin{tabular}{|l|c|c|}
\hline \multicolumn{1}{|c|}{ Variabel } & Cronbach Alpa & Keterangan \\
\hline Pengendalian internal & 0,813 & Reliabel \\
\hline Good governance & 0,874 & Reliabel \\
\hline Pemanfaatan teknologi informasi & 0,744 & Reliabel \\
\hline Kinerja pegawai & 0,895 & Reliabel \\
\hline
\end{tabular}

Sumber : Data Diolah SPSS 26, 2020

Berdasarkan tabel 4.7 diatas dapat dilihat bahwa cronbach'salpha untuk variabel pengendalian internal sebesar 0,813 , variabel good governance sebesar 0,874 , variabel pemanfaatan teknologi informasi 0,744 dan variabel kinerja pegawai 0,895 . Nilai cronbach 'salpha masing-massing variabel penelitian tersebut menunjukkan angka yang lebih besar dari 0,60 yang kontruksi pertanyaan untuk mengukur masing- masing variabel tersebut dinyatakan reliabel.

\subsubsection{Uji Asumsi Klasik}

4.2.3.1 Uji Normalitas

Uji normalitas bertujuan untuk menguji apakah dalam dalam model regresi,variabel penggangu atau residual memiliki distribusi normal dengan melihat grafik Normal Probability Plot. Menurut Ghozali (2011) jika distribusi data residual normal, maka garis yang menggambarkan suatu data residual normal, maka garis yang menggambarkan data sesungguhnya akan mengikuti garis diagonalnya. Hasil uji normalitas dapat dilihat pada grafik P-Plot berikut :

Gambar 4.1

Hasil Normalitas Menggunakan Grafik P-Plot

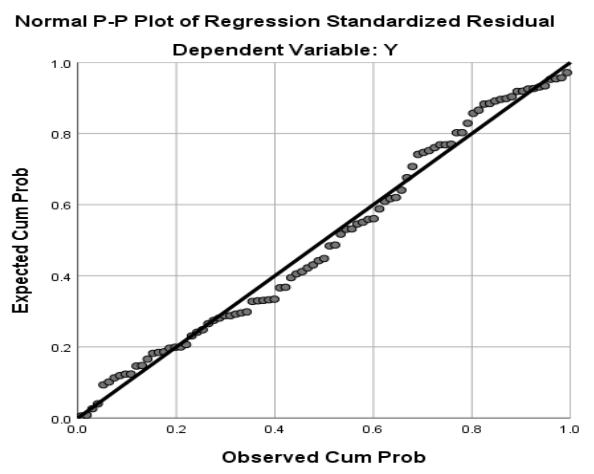

Sumber : Data Diolah SPSS 26, 2020

Berdasarkan gambar 4.1 diatas, penyebaran data berada di sekitas garis diagonal dan mengikuti arah garis diagonal. Hal ini menunjuk kan bahwa model regresi telah memenuhi asumsi normalitas terpenuhi.

\subsubsection{Uji Multikolinearitas}

Uji multikolinearitas bertujuan untuk menguji apakah model regresi ditemukan adanya kolerasi antara variabel bebas (independen). Uji multikoliearitas dilakukan dengan nilai variance inflaction factor (VIF). Nilai yang umum dipakai untuk menunjukkan tidak adanya multikoliearitas adalah VIF $<10$.

4.8

Hasil Uji Multikolinearitas

\begin{tabular}{|c|c|c|c|c|c|c|c|}
\hline \multicolumn{8}{|c|}{ Coefficients $^{\mathrm{a}}$} \\
\hline \multirow[b]{2}{*}{ Model } & \multicolumn{2}{|c|}{$\begin{array}{l}\text { Unstandardized } \\
\text { Coefficients } \\
\end{array}$} & \multirow{2}{*}{$\begin{array}{c}\begin{array}{c}\text { Standardized } \\
\text { Coefficients }\end{array} \\
\text { Beta }\end{array}$} & \multirow[b]{2}{*}{$\mathrm{t}$} & \multirow[b]{2}{*}{ Sig. } & \multicolumn{2}{|c|}{ Collinearity Statistics } \\
\hline & $\mathrm{B}$ & Std. Error & & & & Tolerance & VIF \\
\hline \begin{tabular}{l|l}
1 & (Constant) \\
\end{tabular} & 14.790 & 8.520 & & 1.736 & .086 & & \\
\hline Pengendalian internal & .634 & .120 & .558 & 5.273 & .000 & .754 & 1.326 \\
\hline Good governance & -.241 & .115 & -.239 & -2.086 & .040 & .646 & 1.547 \\
\hline Pemanfaatan teknologi informasi & .357 & .257 & .147 & 1.387 & .169 & .752 & 1.329 \\
\hline
\end{tabular}

a. Dependent Variable: kinerja pegawai bagian keuangan

Sumber : Data Diolah SPSS 26, 2020

Berdasarkan tabel 4.8 diatas dimana terlihat bahwa nilai tolerance untuk variabel pengendalian internal sebesar 0,754, sedangkan good goverance sebesar 0,645 dan variabel pemanfaatan teknologi informasi sebesar 0,752 . Nilai VIF variabel pengendalian internal sebesar 1,326 , variabel good governance

Herda Nengsy - R. Desi Karlina, Pengaruh Pengendalian Internal, Good governance Dan Pemanfaatan Teknologi Informasi Terhadap Kinerja Pegawai Bagian Keuangan pada SKPD di Kabupaten Indragiri Hilir 
sebesar 1,547 dan variabel pemanfaatan teknologi informasi sebesar 1,329. Hasil pengujian menunjukan bahwa nilai tolerance lebih dari 0.10 dan memiliki nilai VIF kurang dari 10 sehingga dapat disimpulkan bahwa tidak terjadi multikolinieritas antara variabel bebas dalam model regresi

\subsubsection{Uji Heterokedastisitas}

Uji heterokedastisitas bertujuan menguji apakah model regresi terjadi ketidaksamaan varians dari residual satu pengamatan kepengamatan lain. Hal ini dapat dideteksi dengan mehihat ada tidaknya pola tertentu pada grafik sctterplot disekitar nilai residual dan variabel dependen suatu penelitian. Jika terdapat pola tertentu maka terjadi heterokadastistas dan jika tidak ada pola tertentu maka tidak terjadi heterokedastistas.

Adapun hasil dari uji heterokedastistas dapat dilihat pada gambar berikut ini:

Gambar 4.2

Uji Hetorokedastistas

Scatterplot

Dependent Variable: $y$

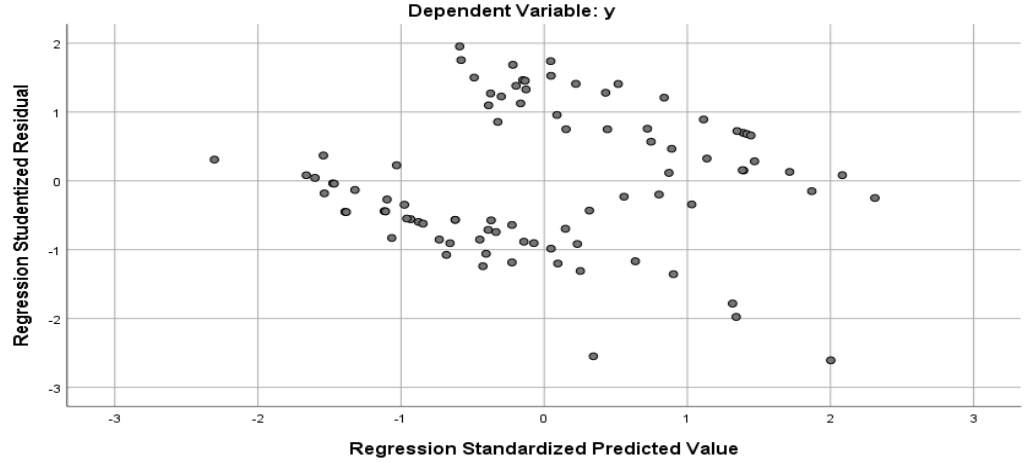

Sumber : Data Diolah SPSS 26, 2020

Berdasarkan gambar 4.2 diatas dapat dilihat pada grafik scatter plot dimana titik-titik tidak membentuk pola tertentu yang jelas, serta tersebar baik diatas maupun dibawah angka nol pada sumbu $\mathrm{y}$, sehingga model regresi layak digunakan.

\subsubsection{Hasil Uji Hepotesa}

\subsubsection{Uji Regresi Linear Berganda}

Uji hipotesis dalam penelitian ini menggunakan model analisis regresi linear berganda, yang bertujuan untuk mengetahui pengaruh variabel independen terhadap variabel dependen. Hasil analisis regresi linear berganda dapat dilihat pada tabel dibawah ini:

Tabel 4.9

Uji Regresi Linear Berganda

\begin{tabular}{|c|c|c|c|c|c|c|c|c|}
\hline \multicolumn{9}{|c|}{ Coefficients $^{\mathrm{a}}$} \\
\hline & & \multicolumn{2}{|c|}{$\begin{array}{l}\text { Unstandardized } \\
\text { Coefficients }\end{array}$} & \multirow{2}{*}{$\begin{array}{c}\text { Standardized } \\
\text { Coefficients } \\
\text { Beta }\end{array}$} & \multirow[b]{2}{*}{$\mathrm{t}$} & \multirow[b]{2}{*}{ Sig. } & \multicolumn{2}{|c|}{ Collinearity Statistics } \\
\hline \multicolumn{2}{|c|}{ Model } & $\mathrm{B}$ & Std. Error & & & & Tolerance & VIF \\
\hline \multirow[t]{4}{*}{1} & (Constant) & 14.790 & 8.520 & & 1.736 & .086 & & \\
\hline & $\begin{array}{l}\text { Pengendalian } \\
\text { internal }\end{array}$ & .634 & 120 & .558 & 5.273 & .000 & .754 & 1.326 \\
\hline & Good governance & -.241 & 115 & -.239 & -2.086 & .040 & 646 & 1.547 \\
\hline & $\begin{array}{l}\text { Prmanfaatan } \\
\text { teknologi informasi }\end{array}$ & .357 & .257 & .147 & 1.387 & .169 & .752 & 1.329 \\
\hline
\end{tabular}

Sumber : Data Diolah SPSS 26, 2020

Berdasarkan tabel 4.9 diatas, hubungan antara variabel independen dan variabel dependen dapat dirumuskan kedalam persamaan sebagai berikut :

$$
Y=14,790+0,634 X 1-0,241 X 2+0,357 X 3+\varepsilon
$$

\subsubsection{Uji Persial (Uji T)}

Uji t digunakan untuk mengetahui variabel dependen pengendalian internal, good governance dan pemanfaatan teknologi informasi secara parsial mempunyai pengaruh yang signifikan terhadap variabel dependen kinerja pegawai bagian keuangan. Adapun hasil dari analisis yang menunjukkan koefesien signifikan disajikan pada tabel berikut.

Herda Nengsy - R. Desi Karlina, Pengaruh Pengendalian Internal, Good governance Dan Pemanfaatan Teknologi Informasi Terhadap Kinerja Pegawai Bagian Keuangan pada SKPD di Kabupaten Indragiri Hilir 
Tabel 4.10

Hasil Uji Secara Parsial

\begin{tabular}{|c|c|c|c|c|c|c|c|c|}
\hline \multicolumn{9}{|c|}{ Coefficients $^{\mathrm{a}}$} \\
\hline & & \multicolumn{2}{|c|}{$\begin{array}{l}\text { Unstandardized } \\
\text { Coefficients }\end{array}$} & \multirow{2}{*}{$\begin{array}{c}\begin{array}{c}\text { Standardized } \\
\text { Coefficients }\end{array} \\
\text { Beta }\end{array}$} & \multirow[b]{2}{*}{$t$} & \multirow[b]{2}{*}{ Sig. } & \multicolumn{2}{|c|}{ Collinearity Statistics } \\
\hline \multicolumn{2}{|c|}{ Model } & $\mathrm{B}$ & Std. Error & & & & Tolerance & VIF \\
\hline \multirow[t]{4}{*}{1} & \begin{tabular}{|l} 
(Constant) \\
\end{tabular} & 14.790 & 8.520 & & 1.736 & .086 & & \\
\hline & $\begin{array}{l}\text { Pengendalian } \\
\text { internal }\end{array}$ & .634 & .120 & .558 & 5.273 & .000 & .754 & 1.326 \\
\hline & Good governance & -.241 & .115 & -.239 & -2.086 & .040 & .646 & 1.547 \\
\hline & $\begin{array}{l}\text { Prmanfaatan } \\
\text { teknologi informasi }\end{array}$ & .357 & 257 & .147 & 1.387 & .169 & .752 & 1.329 \\
\hline
\end{tabular}

Sumber : Data Diolah SPSS 26, 2020

Berdasarkan hasil uji t yang ditunjukkan di atas bahwa variabel pengendalian internal memiliki t hitung 5,273 lebih besar dari nilai t tabel sebesar 1,9882 dan tingkat signifikansinya 0,000 lebih kecil dari tingkat signifikansi yang ditetapkan yaitu 0,05 , maka $\mathrm{H}_{1}$ diterima sehingga dapat disimpulkan bahwa pengendalian internal berpengaruh terhadap kinerja pegawai bagian keuangan.

Good governance menunjukkan nilai t hitung -2,086 lebih kecil dari nilai t tabel sebesar 1,9882 dan tingkat signifikansinya 0,040 lebih kecil dari tingkat signifikansi yang ditetapkan yaitu 0,05 , maka $\mathrm{H}_{2}$ diterima sehingga dapat disimpulkan bahwa good governance berpengaruh terhadap kinerja pegawai bagian keuangan.

Pemanfaatan teknologi informasi menunjukkan nilai t hitung 1,387 lebih kecil dari t tabel sebesar 1,9882 dengan tingkat signifikansinya 0,169 lebih besar dari tingkat signifikansi ditetapkan yaitu 0,05 , maka $\mathrm{H}_{3}$ ditolak sehingga dapat disimpulkan bahwa pemanfaatan teknologi informasi tidak berpengaruh terhadap kinerja pegawai bagian keuangan.

\subsubsection{Uji Simultan (Uji F)}

Uji f signifikan digunakan untuk melihat apakah semua variabel bebas yang dimasukkan dalam model regresi mempunyai pengaruh secara bersama-sama terhadap variabel terkait . Hasil perhitungan seperti tabel berikut :

Tabel 4.11

Uji Hipotesa Secara simultan

\begin{tabular}{|c|c|c|c|c|c|c|}
\hline \multicolumn{7}{|c|}{ ANOVA $^{a}$} \\
\hline \multicolumn{2}{|c|}{ Model } & Sum of Squares & Df & Mean Square & $\mathrm{F}$ & Sig. \\
\hline \multirow[t]{3}{*}{1} & Regression & 1062.318 & 3 & 354.106 & 11.093 & $.000^{\mathrm{b}}$ \\
\hline & Residual & 2713.232 & 85 & 31.920 & & \\
\hline & Total & 3775.551 & 88 & & & \\
\hline
\end{tabular}

a. b. Predictors: (Constant), pengendalian internal, good governance dan pemanfaatan teknologi informasi

Dependent Variable: kinerja pegawai bagian keuangan

Sumber : Data Diolah SPSS 26, 2020

Berdasarkan uji anova pada tabel di atas diketahui bahwa nilai f hitung sebesar 11,093 lebih besar dari f tabel 2,71 dan tingkat signifikansi sebesar 0,000 lebih kecil dari 0,05, sehingga dapat disimpulkan bahwa secara simultan pengendalian internal, good governance dan pemanfaatan teknologi informasi berpengaruh secara signifikan terhadap kinerja pegawai keuangan sehingga $\mathrm{H}_{4}$ diterima.

\subsubsection{Uji Koefisien Determinasi $\left(\left(\mathbf{R}^{2}\right)\right.$}

Koefisien determinasi dilihat dari adjusted $R$ square yang artinya seberapa besar konstribusi variabel terkait. Uji koefisien determinasi yaitu mengukur seberapa jauh kemampuan model dalam menerangkan variasi variabel dependen. Adapun hasil uji koefisien determinasi dapat dilihat pada tabel berikut ini :

Tabel 4.12

Hasil Koefesien Determinasi

\begin{tabular}{|c|c|c|c|c|c|c|c|c|c|}
\hline \multicolumn{10}{|c|}{ Model Summary $^{\mathbf{b}}$} \\
\hline \multirow[b]{2}{*}{ Model } & \multirow[b]{2}{*}{$\mathrm{R}$} & \multirow[b]{2}{*}{$\begin{array}{c}\mathrm{R} \\
\text { Square }\end{array}$} & \multirow[b]{2}{*}{$\begin{array}{l}\text { Adjusted R } \\
\text { Square }\end{array}$} & \multirow{2}{*}{$\begin{array}{l}\text { Std. Error } \\
\text { of the } \\
\text { Estimate }\end{array}$} & \multicolumn{5}{|c|}{ Change Statistics } \\
\hline & & & & & $\begin{array}{l}\text { R Square } \\
\text { Change }\end{array}$ & $\begin{array}{c}\text { F } \\
\text { Change }\end{array}$ & df1 & df2 & Sig. F Change \\
\hline 1 & $.530^{\mathrm{a}}$ & .281 & .256 & 5.650 & 281 & 11.093 & 3 & 85 & .000 \\
\hline
\end{tabular}

a. Predictors: (Constant),pemanfaatan teknologi informasi, good governance, pengendalian internal

b. Dependent Variable: kinerja pegawai bagian keuangan

Sumber : Data Diolah SPSS 26, 2020

Herda Nengsy - R. Desi Karlina, Pengaruh Pengendalian Internal, Good governance Dan Pemanfaatan Teknologi Informasi Terhadap Kinerja Pegawai Bagian Keuangan pada SKPD di Kabupaten Indragiri Hilir 
Pada tabel 4.12 diatas menunjukkan nilai Adjuster $R^{2}$ sebesar 0,256, hal ini berarti 25,6\% variabel kinerja pegawai bagian keuangan dipengaruhi oleh ketiga variabel penjelas yaitu pengendalian internal, good governance dan pemanfaatan teknologi informasi dan sisanya 75,4\% dijelaskan atau dipengaruhi oleh faktor-faktor atau variabel lain yang tidak diteliti dalam penelitian ini.

\subsection{Pembahasan}

4.3.1 Pengaruh Pengendalian Internal Terhadap Kinerja Pegawai Bagian Keuangan Pada SKPD di Kabupaten Indragiri Hilir.

Variabel pengendalian internal memiliki t hitung 5,273 lebih besar dari nilai t tabel sebesar 1,9882 dan tingkat signifikansinya 0,000 lebih kecil dari tingkat signifikansi yang ditetapkan yaitu 0,05 , maka $\mathrm{H}_{1}$ diterima sehingga dapat disimpulkan bahwa pengendalian internal berpengaruh terhadap kinerja pegawai bagian keuanganPada SKPD di Kabupaten Indragiri Hilir. Hal ini menunjukkan bahwa pengendalian internal dibutuhkan agar dapat memberikan keyakinan kepada masyarakat. Pelaksanaan kegiatan yang dilakukan oleh pegawai di lingkungan SKPD telah terlaksana sesuai dengan kebijakan yang dibuat oleh pemerintah.

Menrut Hery (2014) pengendalian internal ini terkait bagaimana individu dalam istansi melaksanakan tugas sesuai dengan wewenang. Pengendalian internal yang berjalan dengan efektif dan efesien secara optimal akan membawa dampak yang baik pada kinerja pegawai bagian keuangan di Kabupaten Indragiri Hilir, terutama pada pegawai bidang keuangan pemerintahan daerah, untuk menghasilkan kinerja yang semakin baik.

Hasil penelitian ini sesuai dengan penelitian yang dilakukan oleh Pangestika (2016), yang menyimpulkan bahwa pengendalian internal berpengaruh terhadap kinerja pegawai bagian keuangan. Hal ini dikarenakan pengendalian internal adalah suatu proses yang terdapat dalam suatu organisasi, dirancang untuk memberikan keyakinan bahwa kegiatan yang dilakukan dalam organisasi sudah sesuai dengan standar kebijakan yang ada.

\subsubsection{Pengaruh Good governance Terhadap Kinerja Pegawai Bagian Keuangan Pada SKPD d Kabupaten Indragiri Hilir.}

Variabel good governance memiliki t hitung -2.086 lebih kecil dari nilai t tabel sebesar 1,9882 dan tingkat signifikansinya 0,040 lebih kecil dari tingkat signifikansi yang ditetapkan yaitu 0,05 , maka $\mathrm{H}_{2}$ diterima sehingga dapat disimpulkan bahwa good governance berpengaruh terhadap kinerja pegawai bagian keuangan pada SKPD di Kabupaten Indragiri Hilir. Hal ini menunjukkan bahwa pegawai keuangan di SKPD di Kabupaten Indragiri Hilir telah memahami good governance dengan baik dan bekerja sesuai dengan aturan yang ada sehingga tidak terjadi keterlambatan dalam pelayanan pablik

Menurut Mardiasmo (2009) good governance atau tata kelola pemerintahan yang baik adalah suatu penyelenggaran manajemen yang solit dan dapat dipertanggung jawabkan secara bersama sehingga tidak menimbulkan kecurangan dalam suatu instansi pemerintahan. Good governance juga berperan sebagai alat ukur menilai kinerja pegawai pemerintahan daerah yang lebih menekankan pada aspek kesejahteraan masyarakat dan pelayanan pablik.

Hasil penelitian ini sesuai dengan penelitian Pangestika (2016) yang menyatakan bahwa good governance berpengaruh terhadap kinerja keuangan. Hasil yang sama juga diuangkapkan oleh Azlina dan Amelia (2014), yang memperoleh kesimpulan bahwa good governance berpengaruh terhadap kinerja pemerintah. Hal ini disebabkan bahwa good governance tata kelola yang baik pada suatu usaha yang dilandasi oleh etika profesional dalam berusaha ataupun berkarya, jika suatu badan pemerintahan dapat menerapkan good governance dengan baik maka pemerintahan tersebut dapat menerapkan sebuah sistem yang dapat mengatur dan mengontrol urusan Negara terkait dengan hak dan kewajiban pihak-pihak didalamnya.

\subsubsection{Pengaruh Pemanfaatan Teknologi Informasi Terhadap Kinerja Pegawai Bagian Keuangan Pada SKPD di Kabupaten Indragiri Hilir.}

Variabel pemanfaatan teknologi informasi memiliki t hitung 5,273 lebih besar dari nilai t tabel sebesar 1,9882 dan tingkat signifikansinya 0,149 lebih besar dari tingkat signifikansi yang ditetapkan yaitu 0,05 maka $\mathrm{H}_{3}$ ditolak sehingga dapat disimpulkan bahwa pemanfaatan teknologi informasi tidak berpengaruh terhadap kinerja pegawai bagian keuangan pada SKPD di Kabupaten Indragiri Hilir. Hal ini menunjukan bahwa teknologi informasi di SKPD Kabupaten Indragiri hilir telah tersedia dengan baik akantetapi para pegawai dilingkungan pemerintahan Kabupaten Indragiri hilir kurang memahami cara memanfaat kan teknologi informasi yang telah tersedia.

Menurut Rantika (2017) pemanfaatan teknologi informasi menjadi peranan penting dalam meningkatkan pelayanan publik karena dengan adanya teknologi informasi dapat meningkatkan kualitas dan kecepatan dalam melayani masyarakat dan pemanfaatan teknologi ini juga dapat membantu akuntan untuk menyelesaikan tugasnya dan meningkat kan kinerja nya.

Hal ini sejalan dengan penelitian Suciani (2016) yang menyimpulakan bahwa pemanfaatan teknologi informasi tidak berpengaruh terhadap kinerja pegawai bidang keuangan. Hal serupa diuangkap kan oleh Rentika (2017) yang menyatakan bahwa pemanfaatan teknologi informasi tidak berpengaruh terhadap

Herda Nengsy - R. Desi Karlina, Pengaruh Pengendalian Internal, Good governance Dan Pemanfaatan Teknologi Informasi Terhadap Kinerja Pegawai Bagian Keuangan pada SKPD di Kabupaten Indragiri Hilir 
kinerja organisasi pemerintah. Selain itu pemanfaatan teknologi informasi merupakan bagian penting dalam organisasi kendala penererapan teknologi informasi antara lain berkaitan dengan kondisi perangkat keras, perangkat lunak yang digunakan, pemutahiran data dan keterbatasan dana.

\section{KESIMPULAN DAN SARAN}

\subsection{Kesimpulan}

Adapun yang dapat diperoleh dari penelitian ini adalah sebagai berikut:

1. Pengendalian internal berpengaruh terhadap kinerja pegawai bagian keuangan Pada SKPD di Kabupaten Indragiri Hilir

2. Good governance berpengaruh terhadap kinerja pegawai bagian keuangan Pada SKPD di Kabupaten Indragiri Hilir

3. Pemanfaatan teknologi informasi tidak berpengaruh terhadap kinerja pegawai bagian keuangan Pada SKPD di Kabupaten Indragiri Hilir

4. Secara simultan pengendalian internal, good governance dan pemanfaatan teknologi informasi berpengaruh secara signifikan terhadap kinerja pegawai

\subsection{Saran}

Adapun saran-saran yang diajukan oleh peneliti dari penelitian yang telah dilakukan antara lain sebagai berikut:

1. Bagi SKPD Kabupaten Indragiri Hilir diharapkan dapat lebih memaksimalkan pelayanan terhadap masyarakat dan lebih diperhatikan agar informasi yang berkaitan dengan pelaporan keuangan daerah dapat diakses dengan mudah oleh masyarakat.

2. Bagi peniliti selanjutnya diharapkan dapat memperluas objek penelitian sehingga data yang diperoleh lebih akurat selain itu menambah variabel-variabel yang berpengaruh terhadap kinerja pegawai bagian keuangan.

3. Bagi peneliti selanjutnya mampu membimbing responden dalam pengisian kuesioner agar tidak terjadi perbedaan maksud antara responden dan peneliti

\section{DAFTAR PUSTAKA}

Akadun, 2009. Administrasi perusahaan negara. Alfabeta. Bandung.

Budiharjo, M. 2015. Panduan Praktis Penilaian Kinerja Karyawan. Cetakan 1- penerbit Raih aksa sukses. Jakarta

Ghozali, Iman. 2011. Aplikasi Analisis Multivariate Dengan Program SPSS, BP Universitas Diponogoro: Semarang

Hery. 2014. Pengendalian Akuntansi Dan Manajemen. Penerbit Kencana. Jakarta

Indrajid, Richarus eko. 2011. Peran Teknologi Informasi Dan Internet. Andi offset: Yogyakarta

Kartika dkk 2012. Good gevironmental governance cetakan pertama. Penerbit UB Press

Mangkunegara, AA. Anwar Prabu. 2016. Manajemen Sumber Daya Manusia. Rosda: Bandung

Mardiasmo. 2009. Otonomi dan Manajemen Keuangan Daerah. Andi: Yogyakarta

Pangestika fierda 2016. Pengaruh Pengendalian Internal, Good Governance Dan Komitmen Organisasi Terhadap Kinerja Pegawai Keuangan Kabupaten Temanggung. Program studi akuntansi fakultas ekonomi universitas negeri Yogyakarta.

Rerung Rintho Rante 2018. E-Commerce Menciptakan Daya Saing Melalui Teknologi Informasi. Cetakan pertama april 2018. Deepublish grup penerbitan CV. Budi utama.

Suciani, Intan. 2016. Pengaruh Komitmen Sumber Daya Manusia, Pemanfaatan Teknologi Informasi, Pengendalian Intern, Pengambilan Keputusan Dan Lingkungan Kerja Terhadap Kinerja Pegawai Bidang Keuangan Pada SKPD Pemerintahan Kabupaten Bintan. Jurusan Akuntansi, Fakultas Ekonomi, Universitas Maritime Raja Ali Haji.

Sugiyono. 2013. Metode penelitian bisnis. Alfabeta : Bandung

Rentika, Indria. 2017. Pengaruh Penerapan Good Governance, Pemanfaatan Teknologi Informasi, Dan Sistem Pemengendalian Intern Pemerintahan Terhadap Kinerja Organisasi Pemerintahan ( Studi Empiris Pada SKPD Di Kota Padang. Fakultas Ekonomi Universitas Negri Padang.

Rini, Sulistyo. 2014. Pengaruh Good Governance Dan Pemanfaatan Teknologi Informasi Terhadap Kinerja Pegawai Keuangan Dinas Pemerintahan Kabupaten Gunung Kidul. Program Studi Akuntansi Fakultas Ekonomi Universitas Negeri Yogyakarta.

http://www.jdih.kemenkeu.go.id/fullText/2014/5TAHUN2014UU.HTM 